\title{
Metaphor as a means of creating a humorous effect in Bulgarian media texts
}

\author{
Elena Stoyanova \\ Konstantin Preslavsky University of Shumen, Bulgaria \\ elvikstoyanova@shu.bg
}

\begin{abstract}
The paper dwells on metaphor as a linguistic means and cognitive mechanism for creating a humorous effect in Bulgarian media texts. There is a similarity between the nature of metaphors and humour. The relation between metaphor and humour is manifested in the comparison of the contradictory and the combination of the disproportionate. The humorous effect created by metaphor in the media discourse is included in the general context and is the result of deliberate efforts, in accordance with pragmatic, linguistic and cultural settings. Despite the universality of humour and metaphor, the interpretation of knowledge, presented through a humorous metaphor, is governed by sociocultural factors. As metaphor is an integral part of media discourse, its implicit functions concur with the functional and pragmatic parameters of said discourse. The collected material allows us to conclude that there are single comic metaphors in Bulgarian media texts, or metaphors which create the humorous effect of a fragment / whole media text based on one or more metaphorical models. In modern Bulgarian media discourse, metaphor is increasingly implemented as a script for the semantic development of the text.
\end{abstract}

Keywords: linguistic and cultural situation, metaphor, media text, humorous effect.

The ridiculous is a mistake or unseemliness that is not painful or destructive...

(Aristotle 2000: 153)

\section{Introduction}

Linguistic and cultural situation (further LCS) is a kind of modelling of the spatio-temporal and socio-cultural continuum. Contemporary Bulgarian LCS is characterized by the activation of the language game, aimed at creating a humorous effect. The ability to create and understand humour is based on the psychophysical basis which regulates the playful attitude of a person to reality (Homo Ludens) in accordance with the logic of creative thinking. Huizinga suggests that play is primary to and a necessary (though not sufficient) condition for the generation of culture (Huizinga 1949). Moreover, the perception of humour evolves in accordance with the changing type of society and culture. Ancient people also had the ability to play. K. G. Krasukhin, in The Notes on the Origins of Humour, writes that, in all 
likelihood, laughter had a ritual, protective function (Arutyunova (ed) 2007: 52). The preliterary forms of the comic (humour) are associated with Greek Dionysian festivities and European medieval carnival processions. The word comic comes from Latin comicus, al.

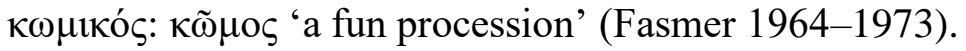

In modern science, humour attracts the attention of researchers of various scientific areas: philosophy, logic, aesthetics, physiology, psychology, literary criticism, linguistics, etc. Humour is defined as the emotional-cognitive structure of a psychophysical and mental nature, functioning according to a dominant principle and objectified in the products of human activity (Utrobina 1997: 31). The phenomenon is an affiliation of language and speech, thinking and culture, and is realized in various types of discourse in accordance with certain pragmatic settings.

In the context of the anthropocentric scientific paradigm, according to which language is perceived as an instrument and mechanism of cognition, a language unit is dependent on the processes of categorization and conceptualization of reality carried out by a person on the basis of accumulated experience and knowledge about the world. In other words, comprehension of mental processes is carried out through language data. Benvenist, in his research "General Linguistics," wrote that language is a structure that carries meaning, and that to think means to operate with signs (Benvenist 2002: 114). Kubryakova and Demyankov, among others, draw attention to the linguistic interpretation of thought (Kubryakova 2004: 14; Kubryakova \& Demyankov 2007: 8-16).

In the light of the abovementioned, the study of humour is closely connected with the theory of metaphor, which is one of means of forming a humorous effect, of representing and structuring information, a tool for displaying mental processes in language, and a way of generating new knowledge. Metaphor is not only a device of poetic imagination and a characteristic of language. It is a necessary instrument of thinking and action. Lakoff and Johnson wrote that "Metaphor is pervasive in everyday life, not just in language but in thought and action. Our ordinary conceptual system, in terms of which we both think and act, is fundamentally metaphorical in nature" (Lakoff \& Johnson 2003: 4-5). Metaphor performs many functions in the text - the functions of conceptualization, categorization, persuasion, heuristics, and aesthetics, etc., and therefore, it is indispensable in media discourse. In interdisciplinary studies, metaphor serves as a nodal, connecting link in the process of interaction of multifarious knowledge. Undoubtedly, the understanding of metaphor (success of communication) depends on the linguistic and cultural competence of the recipient. Modern research is increasingly turning to a comprehensive, joint study of this phenomenon of culture, thinking, and language.

The purpose of this paper is to study metaphors in the context of formation of the humorous effect in Bulgarian media discourse. For this purpose, the following tasks were set: to identify the common ground between metaphor and humour as phenomena of language, thinking and culture, and also to establish the most characteristic mechanisms of metaphor's operation in Bulgarian modern LCS.

\section{Previous research in the field}

Interest in humour historically emerged from philosophical science, and finds its continuation in aesthetics, logic, psychology, literary criticism, and linguistic science. This topic has always attracted the attention of linguists: N. D. Arutyunova (2007), S. Attardo (1994; 2017), S. Bergson (1992), Yu. B. Borev (1970), D. Brzozowska (2011, 2013), J. Huizinga (1949), R. A. Martin (2007), V. Raskin (1985), V. Z. Sannikov (2002), V. N. Teliya (1991), V. V. 
Vasileva (2017), O. P. Yermakova $(1997 ; 2017)$, etc. Despite this interest, the theory of humour requires development within the framework of the anthropological paradigm in the context of discourse. Recently, this kind of research has also manifested an interest in the various aspects of humour in connection with the problems of intercultural communication and linguo-sociocultural situation (Kövecses 2015, Duskaeva (ed) 2018, Dynel 2008; Popova 2018, Sharifian (ed.) 2017, Zemskaya \& Kitaygorodskaya \& Rozanova 1983, etc.). Currently, linguistic humour research acquires cognitive orientation, which is substantiated with the statement that ,the language is an integral facet of cognition which reflects the interaction of social, cultural, psychological, communicative, and functional considerations" (Brône, Feyaerts \& Veale 2006). Cognitive Linguistic analyses humour as a creative phenomenon. Researchers believe that humour may provide a unique insight into the complex interplay of quantitative and qualitative aspects of meaning construction (Goatly 2012; Brône, Feyaerts \& Veale 2006; Brône, Feyaerts \& Veale (ed) 2015; etc.).

Researchers try to differentiate between humour and the funny in a socio-critical direction, despite their partial overlap, by taking physiological laughter out of the bounds of the comical and funny humour that is not accompanied by laughter (Borev 1970: 10; Sychev 2003: 66; Dmitriev and Sychev 2005: 203). Propp writes that humour lies not in the physical nature of man, and not in his/her spiritual nature, but in such a ratio between them in which physical nature reveals the shortcomings of the spiritual one (Propp 2007: 34).

At the heart of humour, according to philosophers (as indicated by Sychev), there is a contradiction between their own advantages and other people's weaknesses (T. Hobbes), between the logical and the absurd (I. Kant), greatness and insignificance (G. Spencer), thoroughness and illusoriness (G. Hegel, K. Marx), by concept and reality (A. Schopenhauer), purpose and means (Z. Freud), alive and mechanistic (A. Bergson) (Sychev 2003: 42). That is why humour is often called a "mistake" (Aristotle 2000), "visible absurdity" (Bergson 1992), etc. In comic situations, there are the factors of surprise and randomness, as identified by Kant and Hegel. Kant connects the emergence of humour with the sudden transformation of tension created by expectation into nothing (Kant 1966: 352), while Hegel, in determining the nature of the humour, lays emphasis on contrast and randomness: the randomness of subjectivity and external circumstances, and the contradictory nature of goals and their nature (Hegel 1971: 581).

The theory of humour studies its typology, genres (comedy, buffoonery, mime, farce, sketch, feuilleton, epigram, parody, caricature, cartoon, etc.), forms (joke and pun), and types (humour, satire, irony, sarcasm, mockery, wit, etc.), as well as describes and analyses the linguistic means used for its formation (units of all levels of language: phonetic, lexicalphraseological, morphological, syntactic), along with the linguistic and stylistic methods and techniques for achieving a humorous effect in various types of discourse. It should be noted that metaphor, along with other linguistic means, is studied in the context of linguistic stylistics. In our opinion, it is the figurative means of language which are actively used to create different forms and types of humour in media discourse that should be given special attention to. Figurative devices help us create the incongruities that are responsible for humour (Kövecses 2015). They serve as cognitive instruments in humour production. Different types of humorous texts involve the creative manipulation of cognitive mechanisms such as metaphor, metonymy, compression, figure/ground alignment, generalization, specialization, etc. (Brône, Feyaerts \& Veale 2006: 20).

The formation of humour is carried out by initiating a contradiction, inconsistency or violation of the norm, moving away from the stereotype caused by the emergence of a second semantic plan, which is created as an intentional or spontaneous/random action, and manifests itself at the language level, at the level of the context or the communicative situation, as well 
as at the level of morals and human nature. Researchers have attempted to explain the cognitive processes underlying specifically humour production and reception (e.g. the incongruity-resolution framework and its refinements) (Dynel 2018: 1-2). It turned out that the basic techniques which create a humorous effect have the same foundation: some of them are based on discrepancies between the expected and the real, while others - on the convergence of distant concepts (see Gorkin (ed.) 2006, Attardo 1994, Raskin 1985, Dynel 2018, etc.).

\section{Material and methods of analysis}

The corpus for this analysis was extracted from modern Bulgarian media. As sources, we used national newspapers: Trud, Politika, Sega, Duma, Dnevnik, Monitor, Standard, etc. News media encompass legacy media, pre-online print and also Internet news media: Actualno, BG News, Blitz, Faktor, Epicenter, Novini 168, Top Novini, etc. and Press agency news media: $B T A$ and Focus. The research focuses on media texts published in the last ten years. The paper analyzes more than 500 media texts of different thematic areas, excerpted by means of free sampling.

The theoretical framework of this research is based on the theory of conceptual metaphor (Rosch 1975; Rosch \& Lloyd (Eds.) 1978; Lakoff \& Johnsen 2003; Fauconnier \& Turner 2008; Baranov \& Karaulov 1991, ets.), contextual theory of metaphor or theory of metaphor in LCS (Kövecses 2015; Stoyanova 2013, 2016), and discourse theories (Teun van Dijk (ed.) 1985; Fairclough 1995, etc.). The complexity and multidimensionality of the object of study determine the application of an integrated approach. We use linguistic methods and cognitive analysis with its set of techniques and procedures related to the linguistic representation of mental processes, in particular, metaphorical modelling. The cognitive understanding of metaphor is associated with its perception as a model for the linguistic representation of the cognitive mechanism for modelling reality and a kind of tool for studying the metaphorical collision of conceptual spheres. The metaphorical model (hereinafter referred to as M-model) is a typical scheme, which plays the role of a kind of axioms of the collective unconscious and represents a certain stereotypical image with the help of which knowledge of the world and the experiences accumulated by a person are organized. Representation and breaking down of a fragment of reality in terms of a different conceptual field is carried out using a frame-slot technique (see Baranov, Karaulov 1991; Minsky 1974; Chudinov 2001, etc.). Frames as an artificial intelligence data structure were proposed by Marvin Minsky in 1974 in his article "A Framework for Representing Knowledge." They are used to divide knowledge into substructures by representing stereotyped situations: "A frame is a data-structure for representing a stereotyped situation, like being in a certain kind of living room, or going to a child's birthday party. Attached to each frame are several kinds of information" (Minsky 1974: 111-112). We use this term to indicate a fragment of a naive picture of the world that structures the corresponding conceptual sphere. Each piece of information about a particular frame is held in a specific mental slot.

The method of discursive and linguo-cultural analysis is closely associated with other methods based on the identification of culturally determined components and extra-linguistic factors in media texts. 


\section{Conceptual base for analysis}

The implementation of humour is represented by metaphorical modelling, where a metaphor as a construct structures and conceptualizes the surrounding reality on the basis of meaningful knowledge, experience, and traditions of a national-cultural community. Metaphor, in this sense, acts as a syncretic way of representing the LCS, which allows us to fix the correlation between the state of society, the development of social consciousness, and its verbal reflection (Stoyanova 2013: 91). Metaphor is based on a cognitive mechanism used to capture similarities and measure seemingly incommensurate and contradictory concepts, thus creating new knowledge on the basis of accumulated experience and tradition. It is no coincidence that a metaphor that does not obey any logic is called "semantic anomaly," "semantic scandal" (Diubua 1986: 195), "intentional deviation from the norm" (Veselovskiy 1940: 442), and "categorical mistake" (Paducheva 2004: 169).

Semantic duplicity of metaphor correlates with the nature of humour. It is the departure from predictability or a deviation from the norm, the destruction of stereotypes in the communicative situation of the interaction of the addresser and the addressee that form the humorous effect. On this basis, metaphor can be considered one of the cognitive mechanisms in the formation of humour. Special expressiveness helps it through realization of pragmatic attitudes of the communicative situation. T. V. Bulygina \& A. D. Shmelev note that, in order to correctly understand intentional anomaly, it is important to establish the purpose which allows the speaker to deviate from the norm (Bulygina \& Shmelev 1990: 104).

The result of cognitive processing and assimilation of new knowledge represented in a metaphor is directly related to the understanding or interpretation of humour. On the one hand, we are dealing with the understanding and interpretation of the information by the authors themselves while, on the other, with the way this is done by the addressee(s). The process of perceiving a metaphor based on a comparison of two semantic plans - the real and the expected - has a subjective character and activates the frames of individual manifestation of consciousness in atypical, unusual associations. Researchers emphasize the ability of metaphor to indirectly and untruly denote an object or a phenomenon (Serebrennikov (ed.) 1988: 96), which creates additional difficulties in its understanding, and expands the possibilities of creative thinking.

In addition, the understanding of humorous metaphor (despite the universality of metaphor and laughter) does not depend only on the education of the addressee and his/her communicative competence; it is additionally complicated by various kinds of socio-cultural codes. It is based on the existence of a wide context defined by culture, the core of which is the linguistic picture of the world (Serebrennikov (ed.) 1988: 28; Demyankov 1983: 58-67). In metaphor, as in the humorous, linguo-cultural experience and tradition are accumulated and broadcast; therefore, they seem culturally conditioned phenomena that are difficult to understand in terms of intercultural communication.

Metaphor is one of the main factors that form the cultural component of a media text, as it allows for better understanding of its content, with the help of vivid, evaluative, often culturally specific images (Dobrosklonskaya 2010: 138). The perception of the humorous effect, which can have a humorous, ironic, satirical, and even grotesque connotation in the media text, is established simultaneously with the realization of a metaphor as a presentation of new knowledge. When metaphor is realized as comprehension of new knowledge, perception of the humorous effect is simultaneously established. Undoubtedly, a comic metaphor enriches consciousness, stimulates cognitive processes, and expands the boundaries within which one understands the world. Indeed, "the borders of my language mean the borders of my world" (Wittgenstein 1994: 90). 
In solving communicative problems in the media, metaphor is an important means of enhancing the desired effect on the will and emotional state of the addressee. In some cases, metaphor could correlate with the phenomenon of "distortion of truth." The humorous effect created by metaphor is potentially aimed at implicitly influencing the consciousness of a mass audience. Such a manipulative effect of metaphor fits well with the functional and pragmatic parameters of media discourse designed not to describe the situation, but to persuade, and by awakening the intentions of the addressee, provide ground for persuasion and induce action, suggesting a certain scheme (Bayley 1985: 104).

In the formation of the humorous effect in media discourse, figurative and new (occasional or author's) metaphors co-occur, which creates a significant expressive effect on the addressee. At the same time, metaphor runs counter to standard ideas about the world and, in the case of fulfilment of a text-forming function, it acts as a script for the deployment of media text, stipulating its coherence and integrity of perception. Studying the textconstructing metaphors corresponds to the modern trends in the development of discourse, which reveals the mechanisms of text construction. In the case of content-conceptual subordination of media text to a certain metaphorical model (hereinafter referred to as $\mathrm{M}$ model), we can no longer speak of a single comic metaphor, but of the humorous effect of a fragment or a whole media text. Increasingly, metaphor in modern media discourse is used as a construct script for the semantic development of the text.

\section{Data analysis}

The analysed material allows us to conclude that the humorous effect in Bulgarian media text is achieved both through the use of single metaphors as well as through text-constructing metaphors aimed at developing the text and creating a humorous effect in a fragment or in the media text as a whole. According to the type of creation and implementation of the humorous effect, media metaphors can be combined into several groups:

\subsection{Conceptual interaction}

Humour based on semantic two-dimensionality of metaphor is determined by the distance between the real and the expected plans, and is accompanied by mandatory implicit evaluation. The use of the M-model relevant in the context of modern LCS in Bulgaria is an important factor for the creation of a humorous effect in media texts.

Spencer points out that metaphor is beneficial if it is "sufficiently simple and understood from a hint" (Spencer 2009: 40). Speaking about maintaining the attention focus as the main requirement of the text, the author wrote that "the power of all forms of speech increases in inverse relation to time and mental effort, which is required from the listener" (Spencer 1999: 705). The specificity of modern LCS in Bulgaria is associated with the intensification of the operation of the culinary metaphor, due to the fact that it is characterized by traditionalism and transmits knowledge which is accessible and understandable to everyone. For example:

Bulgarian - Група влиятелни поддръжници на руския президент Владимир Путин са събрали в книга някои от неговите най-интригуващчи и пиперливи речи и цуитати и са изпратили много бройки от нея в Кремъл, препоръчвайки я като идеален празничен подарък за патриотично настроените държавни служители, предаде Ройтерс. (Новини 168.bg) becomes (literal translation): A group of influential supporters of the Russian President, Vladimir Putin, collected in a book some of his most intriguing and 
peppery (with pepper) speeches and quotes, and sent many copies to the Kremlin, recommending the book as an ideal gift for patriotic government officials, as Reuters reports. (Novini 168.bg).

\subsection{Metaphorization of linguistic and cultural signs}

G. Lakoff and M. Johnson wrote that conceptual metaphors correlate with the main concepts of a particular culture (Lakoff \& Johnson 2003). The humorous effect is obtained through the inclusion of symbolic (and therefore understandable for the native speakers) components of national culture (frequently in non-standard syntagmatic) into the metaphor. For example:

Bulgarian - ГЕРБ и СДС обявиха създаване на предизборна коалииия за съвместно участие в изборите за членове на Европейския парламент от Република България. Безспорен факт обаче са вълненията в дясната част на политическата баница у нас. (Монитор, 21.03.2019). - (literally) GERB and SDS (Bulgarian right-wing political parties) announced the creation of an election coalition for joint participation in the elections of members of the European Parliament from the Republic of Bulgaria. A clear fact is the unrest on the right side of the political banitsa (pie). (Monitor, 21.03.2019).

Banitsa (a kind of pie in Bulgarian national cuisine) is a product from puff pastry. It is a ritual-festive variety of bread and is characterized by symbolism and significance in Bulgarian culture. The main associative frame is its multi-layering - it is precisely this association that immediately arises in the speakers of Bulgarian language. In media text, many political parties operating in Bulgaria, differing in their political programs and ideals, are qualified as a political pie. The humorous effect is built on an illogical syntagmatic-political banitsa.

\subsection{An occasional metaphor for creating a humorous effect}

Renewing the metaphor (creating a new metaphor, an occasional metaphor) is an effective linguistic-cognitive means of expression which strengthens its evaluative and pragmatic potential in Bulgarian media texts. Occasional cognitive metaphors are based on the individual author's ideas about the properties of the signified; therefore, they are assimilated in the language extremely rarely and never lose their imagery. Furthermore, the mechanism of its operation is based on non-standard connotations, semantic or stylistic shades, superimposed on the main meaning. It serves to express an emotionally expressive colouring. But, often, these authoring products are difficult to understand, require speculation, and lead to ambiguous interpretation. In the media discourse, such semantic transformations, coupled with semantic intensity, attract the attention of the addressee.

Frequently, expressiveness is achieved on the basis of precedent phenomena and onyms (included in the cognitive schemata of a person), which, in most cases, have cultural relevance. Onomastic wordplay can be considered a characteristic feature of Bulgarian media discourse (Tsoneva 2017: 100). Bulgarian Prime Minister, Boyko Borisov, often becomes the object of the language game. The occasional use of personal names in texts is often accompanied by a graphic play on words. Occasional metaphors that actualize the associative potential of a proper name carry an emotional charge and create a humorous effect. For example:

Bulgarian - Бойковизацията (Дума, 27.04.2011, бр. 95) becomes (literal translation): Boikovisation (Duma, 27.04.2011, n. 95);

Bulgarian - Бойковчета. Дали наистина тези хора си въобразяват, че вместо пионерчета скоро ще връзват връзки на бойковчета? ... Приликите с онова време, 
което Б.Б. толкова презира, съвсем не са случайни (Дума, 16.06.2011, бр.135), (literal translation): Boiko-neers. Do these people really dream that they will be tying the pioneer red scarves on young Boiko-neers?... The similarities with those times which B.B. so much despises are far from accidental (Duma 16.06.2011, n.135);

Bulgarian - Бойкокрация (Дума, 22.03.2011, бр. 66), (literal translation): Boiko-cracy (from democracy) (Duma, 22.03.2011, n. 66);

Bulgarian - Бойковците се сменят, отношението към Русия остава (Дума, 22.02.2012, бp. 44), (literal translation): Boikos change, the attitude to Russia remains the same (Duma, 22.03.2011, n. 66);

Bulgarian - БОЙКОлонизация. САЩ заставиха България да се откаже от АЕЦ "Белене", послушанието ще ни струва 1 млрд.евро (Дума, 09.04.2012, бр. 84), (literal translation): BOIKOlonisation. The USA forced Bulgaria to give the nuclear power station Belene up, and this obedience will cost us 1 billion euro. (Duma, 09.04.2012, n. 84);

Bulgarian - Бойкономиката: един произвежда, шестима папат (Дума, 30.08.2011, бp. 198), (literal translation): Boikonomics: one creates, six consume (Duma, 30.08.2011, n. 198);

Bulgarian - "Бойкометър" следи за лъжите на властта (Дума, 28.09.2010, бр. 222), (literal translation): Boikometer measures the authorities lies (Duma, 28.09.2010, n. 222);

Bulgarian - Асфалтиране + бойкова власт = реформи (Дума, 16.05.2015, бр. 109), (literal translation): Asphalt + Boiko's rule = reforms (Duma, 16.05.2015, n. 109);

Bulgarian - По-далеч от Бойколандия! (Дума, 03.11.2012, бр. 256), (literal translation): Stay clear of Boikoland! (Duma, 03.11.2012, n. 256);

Bulgarian - Обикновен бойковизъм (Дума, 21.02.2012, бр. 43), (literal translation): ordinary Boikovism (Duma, 21.02.2012, n. 43) и др.

The updated metaphor is also based on borrowed neologisms, which are very popular and actively function in describing the events in other countries. Such examples are related to the term established in Bulgarian language - Maidan - as a type of colour revolution.

For example:

Bulgarian - Днес да изрежем майдановото образувание, преди метастазите му да са разяли тялото на държавата! (epicenter.bg 22.06.2016), (literal translation): Today we should cut out the Maidan formation (tumor) before its metastases ruin the body of the state! (epicenter.bg 22.06.2016);

Bulgarian - Омайданване на демокрацията (Дума 01.03.2014, бр. 50), (literal translation): Transforming democracy by Maidan (Duma, 01.03.2014, n. 50) и др.

Following the model of the Ukrainian Maidan, the metaphor-scenario of Bulgarian Maidan is formed. The occasional nature of this metaphor is the reason why it is being explained in the media text and a reference to the events in Ukraine as the originator of such an initiative is included. There is even a Maidan formula which can be used to name different events of this kind. For example:

Bulgarian - Виктория Нюланд донесе указанията: Утре правят опит за български Майдан.

Утре, както BNews вече писа, ще се направи опит за протест, който е планиран да прерасне в българския Майдан. Впрегнати са всички "професионални революционери", включително и хората на арестувания наскоро за малко Боян Расате. Един от основните негови сподвижници - Александър Кръстев - е подал молбата в Столична община за разрешението на протеста... Посещението на Виктория Нюланд преди около две седмищи в София е било свързано с подготовката на 
протестите. Нюланд е известна като идеолог на украинския Майдан. В София тя се е срещала освен с държавни лища, и с организаторите на платения бунт утре. Формулата на Майдана ще бъде повторена, включително и с финансовото съучастие на Америка. Вече се появиха информации в контролирани сайтове, че САЩ са свалили доверието си от Борисов и планират смяната му. Не е сложно да се открие логическата връзка между напиращите събития и плъзналите слухове. (News.bg 27.01.2016);

becomes (literal translation): Victoria Newland brought the instructions: Tomorrow, there will be an attempt to organize a Bulgarian Maidan.

Tomorrow, as BNews has already written, an attempt will be made for a protest which is planned to turn into a Bulgarian Maidan. All "professional revolutionaries" are summoned; including the partners of recently arrested Boyan Rasate. One of his main accomplices - Alexander Krastev - has filed a request in Sofia Municipality for permission to hold the protests (...). Victoria Newland's visit to Sofia about two weeks ago was related to the preparation of the protests. Newland is known as the ideologist of the Ukrainian Maidan. In Sofia, she met with state officials and the organizers of the paid-for insurgency. The Maidan formula will be repeated, with America's financial support. Information has already emerged on controlled sites that the US has withdrawn its trust from Borisov and is planning to replace him. It is not difficult to find the logical link between the pressing events and rumors. (News.bg 27.01.2016).

\subsection{Metaphor as a scenario}

The humorous effect is based on a complex of pragmatic and linguistic-stylistic features of a metaphor, which serves as a script for the deployment of media text.

Next, we will discuss in more detail the example of using a culinary metaphor which is culturally significant in Bulgarian culture - banitsa, as a heading for a media text. The conceptual metaphor is based on the cognitive model of banitsa - a resource used to perceive and represent the world. In modern media texts, the target sphere is comprised of tangible and intangible goods and human resources. These are the frames which are updated in the following fragments:

„Баницата“ управлява общините.

Многоцветни коалиции по интереси крепят властта на кметовете. (...) Всички са заинтересовани да получат своя дял от общинската баница и никой не иска да подсмърча на сухо в опозицията. (...) Но кметът Атанас Камбитов (ГЕРБ) явно мъдро си бе опекъл работата (Trud 18.11.2015). - (literally) Banitsa (pie) governs the municipalities (administrative units that are part of the region). Multi-coloured coalitions of interests strengthen the power of mayors. (...) Everyone is interested in getting their part of the municipality pie and no one wants to be in opposition with empty hands. (...) But the mayor, Atanas Kambitov (from the GERB party), obviously wisely baked (prepared) the election.

When reading the text, attention is drawn to the headline as the most semantically intense element - dominant semantic. The addressee focuses on it, which gives rise to predictions and expectations about the content of the text. In this case, the frame which comes to the foreground is 'Dishes of national cuisine' (banitsa). The culinary metaphor in this communicative situation attracts attention and causes bewilderment (can a pie rule a municipality?!), contributing to the generation of interest and stimulating the addressee to read on. The following sentence is a generalization of the topic. It is perceived as the key to solving a comic metaphor - it contains an explanation for the title of the media text. The association of similarities (coalitions are banitsa) and the association with the layering of the 
banitsa (as a pastry product) determines an adequate understanding of the colour metaphor, i.e. multi-coloured coalitions, used in the explanation, which is easily perceived by the addressee by correlating the symbolic colour and interests of political parties. However, the conceptual and content information is clarified against the background of the whole text commenting on the diversity of the governing parties against the background of their unanimity (and even the possibility of increasing their quantity) in the struggle to get their piece of the pie - when winning the election. Semantic emphasis is enhanced through the reuse of culinary metaphor, but this time the banitsa (pie) appears already in the form of a material resource - дял от общинска баница - it was from the municipal banitsa (literally part of the banitsa of the municipality). The use of culinary metaphor is also recorded in the actualization of the frame 'cooking technology' - опекъл работата - to be double sure (literally - 'has baked the whole thing' - with baked meaning 'prepared the election procedure and won the election' unhindered). Repetition of culinary metaphor serves as a kind of intensifier. The created intensity, the violation of stereotypical thought processes reflected in the discrepancy between expectation and reality (the so-called effect of "frustrated expectation," according to Jacobson (1960)) creates the humorous effect and causes an ironic reaction in the addressee. The development of the theme (the essence of which is power means wealth and, therefore, everyone strives for power) occurs according to the scheme defined by the culinary M-model (despite the presence of other M-models in this text, it is the culinary metaphor that dominates, and carried the function of a text-building device): banitsa rules - to bake the banitsa (i.e. win the election) - get a piece of municipal banitsa (i.e. get access to material wealth). And finally, the conclusion to which the text leads is: to become a "banitsa" and grab a fatter piece, you need to bake it.

\section{Results and key findings}

Based on the analysis of collected material, it was established that modern Bulgarian media texts actively make use of metaphor as a linguistic means and cognitive mechanism for creating a humorous effect. The semantic duality of metaphor correlates with the nature of humour. The relationship of metaphor and humour is manifested in the comparison of the contradictory and the combination of the disproportionate. Proper understanding of the intended meaning conveyed through a comic metaphor is governed by the sociocultural factor. The implicit functions of metaphor fit into the functional and pragmatic parameters of media discourse, making metaphor an integral part of media discourse. The humorous effect created by metaphor is perceived in accordance with the pragmatic and linguistic settings of media discourse. As a rule, the humorous effect is based on the interaction of distant frames, on the unpredictable valency and questioning of various culturally accepted stereotypes.

There are several groups of metaphors that produce a humorous effect in Bulgarian media texts. Among them, there is metaphor based on the distance between frames, while the conceptual interaction is accompanied by obligatory implicitness. The second group is the creation of a humorous effect by metaphorization of linguistic-cultural signs, including precedent phenomena, units with non-standard syntagmatics, characterized by unpredictability and violation of stereotypical attitudes. The third group includes updated, occasional metaphors used to express and convey the pragmatic potential in the media language. The fourth group includes scenario metaphors, the humorous effect of which is based on a complex of pragmatic and linguistic-stylistic signs. These metaphors serve as a script for the development of media text. The presence of a figurative and occasional metaphor in the media discourse gives it originality and criticality, disguises and smooths out 
information - in a word, contributes to the implementation of its main pragmatic tasks provoking the interpretative abilities of the mass audience.

The collected material demonstrates a number of cases where metaphor is seen as a means of forming a humorous effect in media discourse. Results showed that there are single metaphors which serve as humorous markers in media texts and script metaphors which create the humorous effect of a text fragment or the whole text.

Single metaphors as humorous markers are based on:

- The distance of frames of the metaphorical structure,

- Violation of familiar syntagmatic relationships,

- Various types of wordplay.

A special role in the creation of the humorous effect is played by M-models which are pertinent to LCS, and which are traditional and facilitate the interpretation of accessible and easily graspable knowledge, as well as the metaphorization of linguistic and cultural signs, through which the attention of the recipient is attracted to the object and information that is close to the carrier of the linguistic culture which is transmitted.

A script metaphor creates the humorous effect of a text fragment or the whole text and serves to construct it. Repeated, circular use of a specific M-model in the media text leads to increased expressiveness of the media text itself and leads the readers to the intended interpretation.

\section{Conclusion}

Metaphor in modern Bulgarian media texts is an important language and cognitive mechanism for creating a humorous effect. The humour formation mechanism is based on the cognitive parameters of metaphor, which, in media communication, allows to establish an associative relationship between distant and conflicting conceptual areas, and to use linguistic and cultural signs which are accessible and understandable for the representatives of a given linguo-culture. The presence of a figurative and new (occasional) metaphor in Bulgarian media discourse gives it originality and criticality, disguises and smooth things over. Metaphors contribute to the implementation of the main pragmatic tasks and attitudes of media discourse, and may affect the consciousness of the audience or addressee. Metaphor as a construct-scenario of a Bulgarian media text enhances its expressiveness and guides the addressees to the intended interpretation of the information presented through it.

\section{References}

Aristotle (2000). Ritorika. Poetika [Rhetoric. Poetics]. Moscow: Labirint.

Arutyunova, N. D. (ed.) (2007). Logicheskiy analiz yazyka: yazykovyye mekhanizmy komizma [Logical analysis of language: linguistic mechanisms of comism]. Moscow: Indrik.

Attardo, S. (1994). Linguistic Theories of Humour. N. Y.: Mouton de Gruyter.

Attardo, S. (ed.) (2017). The Routledge Handbook of Language and Humor. New York, NY: Routledge.

Baranov, A. N. \& Karaulov, Yu. N. (1991). Russkaya politicheskaya metafora: Materialy k slovaryu. [Russian political metaphor: Materials for the dictionary]. Moscow: Institut russkogo yazyka. 
Bayley, P. (1985). 'Live oratory in the television age: The language of formal speeches', in Ragazzini, G. \& Miller, D. R. B. P. (eds.), Campaign language: Language, image, myth in the US, Bologna: Cooperativa Libraria Universitaria Editrice Bologna, pp. 77-174.

Benvenist, E. (2002). Obshchaya lingvistika [General linguistics]. [ed. Yu. S. Stepanov; transl. Yu. N. Karaulov]. Moscow: Yeditorial URSS.

Bergson, S. (1992). Smekh [Laughter]. Moscow: Art.

Borev, Yu. B. (1970). Komicheskoye i estetika [Humor and aesthetics]. Moscow: Art.

Brzozowska, D. (2011). 'Humor w tabloidach' [Humour in the tabloids]. Oblicza Komunikacji 4, pp. 209-216.

Brzozowska, D. (2013). 'Demotivators as a new type of media texts'. Media Linguistics 2, pp. 124-126. Retrieved 28 May, 2019 from https://elibrary.ru/item.asp?id=22925086

Bulygina, T. V. \& Shmelev, A. D. (1990). 'Anomalii v tekste: problemy interpretatsii', [Anomaly in the text: problems of interpretation], in Logical analysis of the language: inconsistency and anomaly of the text, Moscow: Science, pp. 94-106.

Chudinov, A. P. (2001). 'Rossiya v metaforicheskom zerkale: kognitivnoe issledovanie politicheskoj metafory (1991-2000)' [Russia in the metaphorical mirror: a Cognitive study of political metaphor (1991-2000)]. Ekaterinburg: Ural State Pedagogical University.

Demyankov, V.Z. (1983) 'Ponimaniye kak interpretiruyushchaya deyatelnost' [Understanding as an interpreting activity]. Linguistics Issues 6, pp. 58-67.

Diubua, Zh. et al. (1986). Obshchaia ritorika [General rhetoric]. Moscow: Progress.

Dmitriyev, A. V. \& Sychev, A. B. (2005). Smekh: sotsiofilosofskiy analiz [Laugh: sociophilosophical analysis]. Moscow: Alfa-M.

Dobrosklonskaya, T. G. (2010). Voprosy izucheniya mediatekstov: Opyt issledovaniya sovremennoy angliyskoy mediarechi [Questions of studying media texts: Experience in the study of modern English media speech]. Moscow: KRASAND.

Duskaeva, L. R. (ed.) (2018). Medialingvistika v terminakh i poniatiiakh. Slovar'-spravochnik [Medialinguistics in terms and concepts. A reference's dictionary]. Moscow: Flinta.

Fasmer, M. R. (1964-1973). Etimologicheskiy slovar russkogo yazyka [Etymological dictionary of the Russian language]. Moscow: Progress.

Gegel, G. V. F. (1971). Estetika III [Esthetics III], Moscow: Science.

Gorkin, A. P. (ed.) (2006). Literatura i yazyk [Literature and language]. Modern Illustrated Encyclopedia. Moscow: Rosmen.

Kant, I. (1966). Sochineniya v 6 tomakh. [Works in 6 volumes]. Vol. 5. Moscow.

Khoyzinga, Y. (1992). Homo ludens. V teni zavtrashnego dnya [Homo ludens. In the shadow of tomorrow]. Moscow: Progress.

Kubryakova, Ye. S. (2004). Yazyk $i$ znaniye: Na puti polucheniya znaniy o yazyke: Chasti rechi $s$ kognitivnoy tochki zreniya. Rol yazyka $v$ poznanii mira [Language and knowledge: Towards knowledge of a language: Parts of speech from a cognitive point of view. The role of language in cognition of the world]. Moscow: Yazyki slavyanskoy kultury.

Kubryakova, Ye.S. \& Demyankov, V. Z. (2007). 'K probleme mentalnykh reprezentatsiy' [About the problem of mental representations]. Cognitive Linguistics Issues 4 (013), 816.

Lakoff, G. \& Johnson, M. (2003). Metaphors we live by. London: The university of Chicago press.

Minsky, M. (1975). A Framework for Representing Knowledge, in Winston, P. H. (ed.), The psychology of computer vision. New York: McGraw-Hill Book. 
Paducheva, E. V. (2004). Dinamicheskie modeli v semantike leksiki [Dynamic models in the semantics of vocabulary]. Moscow: LRC Publishing House.

Propp, V. Ya. (2007). Problemy komizma i smekha. Ritualnyy smekh v folklore [The problems of humor and laughter. Ritual laughter in folklore]. Moscow: Art.

Popova, T. I. (2018). 'Aktual'nye napravleniia issledovaniia mediinogo internet-prostranstva [Actual directions of media internet space investigation]', in Media Linguistics 5 (3), pp. 258-272.

Raskin, V. (1985). Semantic Mechanisms of Humor. Dordrecht: D. Reidel Publishing Company.

Sannikov, V.Z. (2002). Russkiy yazyk v zerkale yazykovoy igry [Russian language in the mirror of the verbal play]. Moscow: Languages of Slavic culture.

Serebrennikov, B. A. (ed.) (1988). Rol' chelovecheskogo faktora v yazyke: Yazyk i kartina mira [The role of the human factor in language: Language and the picture of the world]. Moscow: Science.

Spenser, G. (1999). Opyty nauchnyye, politicheskiye i filosofskiye [Scientific, political and philosophical experiences]. Vol. 2. Mn.: Sovremen. Literator.

Stoyanova, Ye. (2013). Metafora skvoz prizmu lingvokulturnoy situatsii [Metaphor through the prism of a linguocultural situation]. Shumen: UPH „Yepiskop Konstantin Preslavski“.

Sychev, A. A. (2003). Priroda smekha ili Filosofiya komicheskogo [The nature of laughter or the philosophy of the humor]. Moscow: PH MGU.

Teliya, V. N. (ed.) (1991). Chelovecheskiy faktor $v$ yazyke. Yazykovyye mekhanizmy ekspressivnosti [The human factor in language. Linguistic mechanisms of expressivity]. Moscow: Science.

Tsoneva, L. (2017). Imena i lyudi. Klyuchevyye imena v mediadiskurse [Names and people. Key names in the media discourse]. Veliko-Tyrnovo: Ivis.

Utrobina, T. G. (1997). 'Yazykovyye sredstva reprezentatsii kontseptualnoy kartiny mira (na materiale satiricheskikh rasskazov M. M. Zoshchenko 1920-kh godov)' [Language means of representing the conceptual picture of the world (based on the material of satirical stories by M. M. Zoshchenko of the 1920s)], in Text: structure and functioning 2. Barnaul: Altai University Publishing House, pp. 72-81.

Vasileva, V. V. (2017). 'Anekdot v professional'nom mediatekste: pereprofilirovanie rechevogo zhanra' [Anecdote in professional media text: re-profiling of the speech genre], in Media Linguistics 4 (19), pp. 80-89. Retrieved 12 April, 2019 from https://medialing.ru/anekdot-v-professionalnom-mediatekste-pereprofilirovanierechevogo-zhanra/

Veselovskiy, A. N. (1940). 'Psikhologicheskiy parallelizm i yego formy $\mathrm{v}$ otrazhenii poeticheskogo stilya' [Psychological parallelism and its forms in the reflection of poetic style], in Historical poetics L, pp. 125-199.

Wittgenstein, L. (1994). Filosofskiye raboty [Philosophical researches]. Part 1. Moscow: Gnozis.

Yermakova, O. P. (1997). 'Ob ironii i metafore' [About irony and metaphor], in Word guise. Moscow: Russian dictionaries, pp. 48-57.

Yermakova, O. P. (2017). Ironiya i yeye rol v zhizni yazyka: uchebnoye posobiye [Irony and its role in the life of a language: a textbook]. Moscow: Flinta.

Zemskaya, Ye. A. \& Kitaygorodskaya, M. A. \& Rozanova, N. N. (1983). 'Yazykovaya igra' [Verbal play], in Russian spoken speech. Phonetics. Morphology. Vocabulary. Gesture. Moscow: Science, pp. 172-214. 